\title{
Assessment of Knowledge, Attitude, and Practice on Voluntary Blood Donation in Shkodra City
}

\author{
Vera Asllani Gjinaj, MA. \\ Zamira Shabani, Prof. Ass. PhD, MA. \\ Kristjana Pjetergjokaj \\ University “ Luigj Gurakuqi ”, Sheshi "2 Prilli”, Shkodër, Albania
}

Doi: 10.19044/esj.2018.v14n30p206 URL:http://dx.doi.org/10.19044/esj.2018.v14n30p206

\begin{abstract}
Blood is a liquid mass that is produced from the bone marrow and it circulates in our body. The only source for donation is by a human. In Shkodra City, the main donation is the family donation and about 400 units are provided by voluntary donation organized by the Albanian Red Cross, Shkodra Branch. These voluntarily donated units go mainly for people suffering with thalassemia. This study is a cross-sectional, transversal, punctual, and descriptive study. It was developed from January - March 2018 in Shkodra region among volunteer blood donors. The people who have been offered as volunteers of blood donation during this period (about one hundred people) have previously completed a standardized closed questionnaire. This questionnaire was self-reported with their permission. All the collected data was analyzed by SPSS version 20 Program.
\end{abstract}

Keywords: Blood donation, knowledge, practice, voluntary

\section{Introduction}

Blood is a fluid mass that circulates in the veins and arteries with the function of supplying oxygen to the tissues and nutrition, transporting hormones and several products, organizes the protective system, and eliminates $\mathrm{CO} 2$ and the final products of metabolism. Blood is composed of plasma and figurative elements, such as erythrocytes, leukocytes and thrombocytes, which are used for producing serum as well (Burke \& Lemone, 2004; Scherer, 1991). Humans still remain the only source of blood donation for saving lives in need of blood. The Red Cross of Albania provides Blood Transfusion Service of about $6500-7000$ blood units within a year, which were offered by volunteer donors. The demand for blood is much bigger than what voluntary donation gives. The Voluntary and Free Blood Donation Promotion Program in Albania started in 1993, and was supported by the International 
Federation of Red Cross and Red Crescent Societies in agreement with the Ministry of Health (RCA, 2017). Blood donation sessions met the criteria established by The World Health Organization (WHO) which recommended integrated strategy for blood safety and availability. Before blood donation, donors are tested for hemoglobin levels, the arterial tension is measured, and a questionnaire is completed to evaluate the general health condition. Also, before the blood is donated to people in need, it is tested for hepatitis B, hepatitis C, syphilis, and HIV / AIDS. It is only after we are ensured that it is safe that it is then transfused to people in need. Blood processing is carried out by the National Blood Transfusion Center which provides analysis for each donor. The donation technique is implemented in accordance with all rules of the asepsis (WHO, 2012).

The blood donation process and the voluntary blood donation in particular provide to the donor great health benefits. In addition, we can emphasize that by the end of 2004, there were 149 HIV cases in Albania (WHO, 2006).

Shkodra's data on blood transfusion needs for 2000-2010 show that the transfused population accounts for $0.2 \%$ of the population (Shabani, 2011). Unfortunately, the number of people infected with HIV nowadays is increasing, and also those who are infected with HBV, HCV, and syphilis. According to American Red Cross, researches published in 2012 in United States of America demonstrated that the repetition of blood donation was effective in reducing blood pressure, blood glucose, HbA1C, low-density lipoprotein/high-density lipoprotein ratio, and heart rate in patients with metabolic syndrome making blood donation not only effective in testing health problems, but also to have other biological benefits (RCA, 2017).

\section{Material and Methods}

The population under the study includes people which are voluntarily offered to donate blood in the sessions organized by the Albanian Red Cross, branch of Shkodra. This paper focuses on evaluating the knowledge that these people have about blood donation and it also provides more knowledge about the attitude and the practices of this process.

This is a cross-sectional, transversal, punctual, qualitative, and descriptive study. We have also described the assessment, attitude, and practice of voluntary blood donation. Being in the position of coordinator of the Voluntary Blood Donation Project at Red Cross Albania, Shkodra Branch, we had an agreement with Ministry of Health of Albania and Ministry of Education of Albania to collaborate with the Albanian Universities. It was developed from January -March 2018 in Shkodra region among volunteer blood donors. The people who offered blood donation during this period (about one hundred people) have previously completed a standardized closed 
questionnaire. This questionnaire was self-reported with their permission. All the collected data was analyzed by SPSS version 20 Program because it is the best program to be used in analyzing the questionaries.

\section{Results and Discussions}

The people who have been offered as volunteers of blood donation during sessions, organized by the Albanian Red Cross, Shkodra branch, for the period of time January - March 2018 have completed a standardized questionnaire about blood donation. The first part of the questionnaire contains socio-demographic data, while the rest part consists of 21 questions where the information collected from them is divided into 4 components; knowledge of blood groups, knowledge of blood donation, attitudes, and practices of blood donation.

Table 1. Socio - Demographics data

\begin{tabular}{llll}
\hline Gender & $\%$ & Education & $\%$ \\
\hline Female & $79 \%$ & High school & $3 \%$ \\
Male & $21 \%$ & University & $97 \%$ \\
Age group & & Marital status & \\
18-20 year & $62 \%$ & Single & $82 \%$ \\
\hline $21-45$ year & $34 \%$ & Married & $13 \%$ \\
\hline$>45$ year & $4 \%$ & No response & $5 \%$ \\
Employment & & Religion & \\
Student & $81 \%$ & Muslim & $39 \%$ \\
Unemployed & $7 \%$ & Catholic & $53 \%$ \\
Employed & $11 \%$ & No response & $8 \%$ \\
\hline Self employed & $1 \%$ & & \\
Residence & & & \\
Urban areas & $51 \%$ & & \\
Rural areas & $49 \%$ & & \\
\hline
\end{tabular}

Table 1 presents socio-demographics data of respondents. Related to the data from the first table, on the socio-demographic information, we see that the imminent numbers of donors are females at $79 \%$. The greatest number of voluntary blood donors has a university education, $97 \%$, and the average age is 22.62 years old. This is explained by the fact that the largest number of voluntary donations was done at the university where the attendants are more appropriate for blood donation. $81 \%$ of voluntary blood donors are students, $11 \%$ employed, and $7 \%$ unemployed. Regarding the religion of donors, the data shows that $53 \%$ are of the Christian faith, 39\% Muslim, and $8 \%$ have not declared their beliefs. 
Table 2. Knowledge of blood groups

\begin{tabular}{lllc}
\hline $\begin{array}{l}\text { 1. Do you know the common } \\
\text { blood groups? }\end{array}$ & $\%$ & $\begin{array}{l}\text { 5.What diseases are } \\
\text { transmissible } \\
\text { by blood transfusion? }\end{array}$ & $\%$ \\
\hline YES & & HIV & $91 \%$ \\
\hline NO & $99 \%$ & HBV & $35 \%$ \\
& $1 \%$ & HCV & $26 \%$ \\
\hline $\begin{array}{l}\text { 2. Do you know your blood } \\
\text { group? }\end{array}$ & $\%$ & Syphilis & $28 \%$ \\
YES & $83 \%$ & CMV & $4 \%$ \\
NO & $17 \%$ & Other infections & $7 \%$ \\
& & 4. Can a person be infected by & $25 \%$ \\
\hline 3. Blood group of respondent? & $\%$ & YES & $\%$ \\
\hline A negative & $1 \%$ & NO & $65 \%$ \\
\hline A positive & $28 \%$ & & $35 \%$ \\
B negative & $1 \%$ & 6. How often can an individual donate? \\
\hline B positive & $13 \%$ & Weekly & $2 \%$ \\
\hline O negative & $4 \%$ & Monthly & $2 \%$ \\
\hline O positive & $31 \%$ & 3 Monthly & $50 \%$ \\
\hline AB negative & $2 \%$ & 6 Monthly & $40 \%$ \\
\hline AB positive & $6 \%$ & Annually & $3 \%$ \\
\hline No response & $14 \%$ & No answer & $3 \%$ \\
\hline & & & \\
\hline
\end{tabular}

Table 2 presents the data on the knowledge of blood groups. According to the data, $99 \%$ of respondents know theoretically the blood groups, while $83 \%$ know their blood group. Regarding the frequency of blood groups among the volunteer donors, we see that the largest percentage is $\mathrm{O}$ positive, with $31 \%$, then A positive group with $28 \%$ of cases, and the third B positive group with $13 \%$ of cases. Only $8 \%$ of respondents who know their blood group are negative Rhesus. Most of the respondents, about 91\%, have information on transmitting HIV infection through blood. However, a relatively low percentage of people have information that serious infections, such as HBV (35\%), HCV (26\%) or syphilis (28\%), can be transmitted. Most of the respondents, respectively $65 \%$, suggest that a person may be infected through blood transfusion. This indicates that they lack information on pre-existing blood control, whether by family or voluntary donation. Mostly, the blood is checked at the National Blood Transfusion Center in Tirana. As for the question in regards to the frequency of blood donations, $90 \%$ refer to donations every 3-6 months. A male donates maximum of 4 times a year (every three months), while a female donates maximum of 3 times a year (every 4 months). 
Table 3. Knowledge of blood donation

\begin{tabular}{|c|c|c|c|}
\hline 7. Who should donate blood? & $\%$ & $\begin{array}{l}\text { 8. Who should not } \\
\text { donate blood? }\end{array}$ & $\%$ \\
\hline Men & $50 \%$ & Men & $0 \%$ \\
\hline Women & $51 \%$ & Women & $0 \%$ \\
\hline Young & 51 & Young (<18 years) & $26 \%$ \\
\hline$(<18$ years $)$ & $1 \%$ & Old $(>60$ years $)$ & $22 \%$ \\
\hline Old ( $>60$ years $)$ & $0 \%$ & Healthy & $0 \%$ \\
\hline Healthy & $81 \%$ & Diseased & $96 \%$ \\
\hline Diseased & $0 \%$ & Religious belief & $1 \%$ \\
\hline $\begin{array}{l}\text { 9. What volume of blood is collected } \\
\text { during each donation? }\end{array}$ & $\%$ & $\begin{array}{l}\text { 10. What is the } \\
\text { duration of a } \\
\text { donation process? }\end{array}$ & $\%$ \\
\hline$<400 \mathrm{ml}$ & $91 \%$ & $<20$ minutes & $92 \%$ \\
\hline $500-100 \mathrm{ml}$ & $2 \%$ & 20-60 minutes & $5 \%$ \\
\hline Don't know & $7 \%$ & Don’t know & $3 \%$ \\
\hline
\end{tabular}

Table 3 presents the data on the knowledge of the respondents about the blood donation process. These data indicate that $81 \%$ of respondents think that healthy people are the most suitable for blood donation. $51 \%$ refer that blood donors may be even younger than 18 years old. In our country, blood donation is not allowed under the age of 18 , but there are countries around the world where the law allows the donation from 16 to 65 years old. $91 \%$ of the respondents said that the amount donated is $<400 \mathrm{ml}$, while $7 \%$ do not know. $92 \%$ refer that the donation process takes less than 20 minutes.

Table 4. Attitude towards blood donation

\begin{tabular}{|c|c|c|c|}
\hline $\begin{array}{l}\text { 11. What do you think about } \\
\text { blood donation? }\end{array}$ & $\%$ & $\begin{array}{l}\text { 12. What do you think is the } \\
\text { best source of donor blood? }\end{array}$ & $\%$ \\
\hline Good & $94 \%$ & Voluntary donor & $94 \%$ \\
\hline Bad & $2 \%$ & Replacement donor & $20 \%$ \\
\hline \multirow[t]{2}{*}{ Neutral } & $4 \%$ & Remunerated donor & $2 \%$ \\
\hline & & Self-donor & $0 \%$ \\
\hline $\begin{array}{l}\text { 13. Can something happen to a } \\
\text { blood donor during or after } \\
\text { donation? }\end{array}$ & $\%$ & & \\
\hline YES & $62 \%$ & $\begin{array}{l}\text { 14. What can happen to a blood } \\
\text { donor during or after donation? }\end{array}$ & $\%$ \\
\hline $\mathrm{NO}$ & $26 \%$ & Contract infection & $19 \%$ \\
\hline \multirow[t]{2}{*}{ No response $=\mathbf{3}$} & $12 \%$ & Temporary weakness & $60 \%$ \\
\hline & & Fall sick & $5 \%$ \\
\hline $\begin{array}{l}15 . \text { Should patient relatives be } \\
\text { asked to donate? }\end{array}$ & $\%$ & Don't know & $19 \%$ \\
\hline YES & $94 \%$ & & \\
\hline NO & $6 \%$ & & \\
\hline
\end{tabular}

Table 4 presents the data on attitudes that respondents have about the blood donation process. Most of the respondents have expressed that they have a positive attitude towards blood donation. 94\% said that voluntary donation 
is the best donation, followed by family donation with $20 \%$. Regarding to question no. 13, $62 \%$ of the respondents suggest that donation may have side effects, mainly temporary fatigue that is possible in some people after donation. We emphasize that $19 \%$ of the people refer to the possibility of infection, and 5\% refer to the possibility to fall sick. However, this is a fact that is not true because the donors are tested in advance, and only if they meet the health conditions they may become donors.

Table 5. Practice of blood donation

\begin{tabular}{|c|c|c|c|}
\hline $\begin{array}{l}\text { 16. Have you donated } \\
\text { before? }\end{array}$ & $\%$ & 18. Why did you donate? & $\%$ \\
\hline YES & $70 \%$ & A friend or relative needed blood & $9 \%$ \\
\hline \multirow[t]{2}{*}{ NO } & $30 \%$ & Voluntary & $95 \%$ \\
\hline & & Remuneration & $0 \%$ \\
\hline $\begin{array}{l}\text { 17. How often do you } \\
\text { donate? }\end{array}$ & $\%$ & To know my screening status & $10 \%$ \\
\hline$<1$ time a year & $69 \%$ & & \\
\hline $1-3$ times a year & $28 \%$ & $\begin{array}{l}\text { 20. Reasons for no donation by non- } \\
\text { donors }\end{array}$ & $\%$ \\
\hline \multirow[t]{2}{*}{$>3$ times a year } & $3 \%$ & Not approached to donate & $0 \%$ \\
\hline & & Unfit to donate & $10 \%$ \\
\hline \multicolumn{2}{|c|}{$\begin{array}{l}\text { 19. Will you donate if called upon o } \\
\text { reminded to do so? }\end{array}$} & $\begin{array}{l}\text { or Need to donate for friends or relatives } \\
\text { in future }\end{array}$ & $0 \%$ \\
\hline YES & $95 \%$ & Fear of needles & $3 \%$ \\
\hline NO & $2 \%$ & Fear of knowing my status & $0 \%$ \\
\hline \multirow[t]{2}{*}{ Don’t know } & $3 \%$ & & \\
\hline & & $\begin{array}{l}22 \text {. Which is the best source of information } \\
\text { related to voluntary blood donation? }\end{array}$ & $\%$ \\
\hline $\begin{array}{l}21 . \text { Do you encourage } \\
\text { relatives to donate? }\end{array}$ & $\%$ & School & $87 \%$ \\
\hline YES & $93 \%$ & TV & $27 \%$ \\
\hline \multirow[t]{4}{*}{ NO } & $7 \%$ & Social sources & $23 \%$ \\
\hline & & Red CROSS & $68 \%$ \\
\hline & & Relatives & $1 \%$ \\
\hline & & Other sources & $3 \%$ \\
\hline
\end{tabular}

Table 5 presents the data on the practices of respondents about the blood donation process. $70 \%$ of respondents referred to have donated blood before. Thus, this is a fact which indicates that the donation has left a positive impact on these people. 95\% of people affirm to have donated blood voluntarily and are willing to donate again if they are asked to. The reasons for no donation by non-donors are unfit to donate related to health problems such as anemia, low blood tension, and various diseases. $10 \%$ and $3 \%$ refer that they are afraid of needles. A positive behavior is the encouragement that donors give to their family to donate blood, of which $93 \%$ refer to a positive attitude. The main source of information is the school with $87 \%$, Red Cross with $68 \%$, TV and social networks with $27 \%$ and $23 \%$. 


\section{Conclusion}

Voluntary and free blood donation is a good opportunity for the continuous health testing of the individuals. However, the most important of them is in saving and contributing to the lives in need. The Albanian Red Cross, Shkodra branch, provides about four hundred units of blood to meet the needs of individuals suffering with thalassemia. The majority of people who have been offered for blood donation are those with a bachelor education, including the average age of 23 years old which perfectly fits with most active and healthy age. Most of the donors have expressed a positive feedback about the blood donation process. They are always ready for the next step, and are also ready to invite and encourage others to join in. The majority of the respondents emphasize that voluntary and free blood donation is the best and safest source of providing blood. This source of blood collection is wellknown all around the world because the provided blood is safe since many tests are performed, and also the individuals are free to complete the questionnaire. Most of the respondents express their fear of getting infected by blood transfusion. Thus, this happens when there is a lack of information about the blood test in advance. There is a lack of information even about how infections, such as HBV, HCV and Syphilis, are transmitted through our blood. The main source of information is school and the Albanian Red Cross. This indication must encourage us to share information across social networks, TV, etc. All these efforts will be available for the future to change behaviors through knowledge growth about blood donation. Consequently, we hope to provide more blood units for the Shkodra Regional Hospital and for the people suffering with thalassemia.

\section{References:}

1. Burke, C. \& Lemone, P. (2004). Medical Surgical Nursing. New Jersey.

2. http://www.kksh.org.al/old/index 2. php? $\mathrm{f}=$ details\&id=66\&n=con\&mn $\underline{\mathrm{u}}=37$

3. https://en.wikipedia.org/wiki/Blood_donation

4. Scherer, J. (1991). Medical Surgical Nursing. Philadelphia

5. Shabani, Z., Gjinaj, V. \& Qirjako, G. (2011). "The Situation of Blood Donation and Needs in Shkodra Region". Albanian Medical Journal No.4-2011. Pg 32-40.

6. World Health Organization (2006). Regional Office for Europe. HIV/AIDS in Europe: Moving from death sentence to chronic disease management. Copenhagen.

7. World Health Organization (2012). Guidelines on Assessing Donor Suitability for Blood Donation. Switzerland. 